\title{
Relevance of cognitive dissonance, activation and involvement to branding: An overview
}

\section{Relevancia de la disonancia cognitiva, la activación y el implicación en el branding: un resumen}

\author{
Arti Sahgal and Achim Elfering \\ Institute of Psychology, Department for Work and Organizational Psychology at the University of Berne, Switzerland
}

Disponible online 31 de diciembre de 2011

\begin{abstract}
This study examines consumer behavior from the perspective of cognitive psychology. It focuses on a set of cognitive psychological determinants of buyer behavior and analyzes how cognitive dissonance, activation and involvement influence consumer behavior. The literature indicates that a deeper insight into the cognitive processes underlying purchase behavior is essential for brand managers to create and communicate interventions that may have a stronger impact on the buyer such that their brand occupies a special position in the consumer's mind. Up to now, the conflict between presenting a brand in a both favorable light and completely accurately has been rarely addressed in the literature.
\end{abstract}

Keywords: Branding; Consumer Behavior; Cognitive Processes; Cognitive Dissonance.

En este trabajo se examina el comportamiento del consumidor desde la perspectiva de la psicología cognitiva. Este artículo se centra en una selección de determinantes psicológicos cognitivos en la conducta del comprador y analiza cómo la disonancia cognitiva, la activación y la implicación tienen especial influencia sobre el comportamiento del consumidor. La bibliografía demuestra que es indispensable adquirir una mayor comprensión de los procesos cognitivos que afectan a las conductas de compra de los consumidores, de tal manera que los gerentes de las marcas puedan crear y transmitir intervenciones que tengan un profundo impacto en el comprador y que logren que su marca ocupe una posición distintiva en la mente del consumidor. Se considera que hasta ahora, no se ha investigado suficientemente el conflicto entre cómo presentar una marca de manera que ésta se vea beneficiada y cómo presentarla de manera veraz.

Palabras Clave: Branding; Comportamiento del Consumidor; Procesos Cognitivos; Disonancia Cognitiva.

Correspondence concerning this article should be addressed to: Prof. Dr. Achim Elfering, University of Berne Institute of Psychology, Department for Work and Organizational Psychology, Muesmattstrasse 45. 3000 Bern 9 E-mail: achim.elfering@psy.unibe.ch. Author’s e-Mails: Arti Sahgal: arti@sahgal.ch 
Brands accompany people throughout their entire life. Notions like Nike, Coca-Cola or UBS are familiar to us since early childhood; they stand for continuity and safety in our being (Waller, Süss, \& Bircher, 2006). By means of our behavior as consumer we can symbolize who we are, some even go to the extent of claiming "you are what you consume" (Solomon, 2002, p. 135).

It is no secret that in industrial countries we nowadays are living in a society of abundance. In our markets a growing saturation can be observed due to which on the supply-side products are always becoming more homogeneous and thus replaceable. In many markets in the course of time the position of suppliers has weakened due to this occurrence of saturation and for this reason, extraordinary communication efforts have become necessary to promote sales. In such flooded markets with less involved consumers (see section Consumer Involvement) and functionally interchangeable products, a strong as well as differentiating brand positioning is vital to set oneself apart from competition (Day, 1990).

Naturally all suppliers want to make their voice heard by potential customers, in order to promote the provided brand (Aaker, 1996). But just in today's time of communication exuberance it is particularly challenging to catch the attention of consumers (Ries \& Trout, 1981; Trommsdorff \& Paulssen, 2005). Because of the increasing information overload with advertising messages on the customer-side (see section Perception and Attention), sales companies are forced to design their communication messages in such a manner that they grasp attention and activate the target group (see section Activation of Consumers; De Pasquale \& Leschnikowski, 2007). But the resulting communication and promotion flood, leads to the fact that it is getting continuously more difficult to be perceived by customers. Accordingly, to nevertheless be able to prove oneself and be victorious in this increasingly intensive rat-race, a differentiating and successful positioning of brands is crucial (Aaker, 1996).

According to Ries and Trout (1981) who are considered the originators of the positioning concept, success without a clear positioning is not possible. They define positioning as follows:

"Positioning starts with a product. . . But positioning is not what you do to a product. Positioning is what you do to the mind of the prospect. That is, you position the product in the mind of the prospect." (Ries \& Trout, 1981, p. 2 f).

On ground of the above described conception of branding, it becomes evident that in order for brand providers to create and communicate interventions that have an impact on the customer, it is of great importance to understand the psychological processes underlying consumer behavior and to know in what manner they determine a customer's likes or dislikes towards brands. This knowledge enables the supplier to influence buyers and therefore, the comprehension of what takes place in the psyche of the customer embodies a key success factor for brand management. For obvious reasons, psychological approaches play a considerable role in this context and ultimately assist in understanding as well as predicting consumer behavior.

Within the scope of the present paper, the aim is to review and to point out the pertinence of psychological models and theories, particularly from a cognitive perspective on consumer behavior, that are most commonly mentioned in conjunction with branding. The following section is dedicated to the general relevance of psychology in the context of brand management and to theoretical approaches to consumer behavior. In the subsequent chapters selected well-established cognitive concepts and theories, especially relevant to anchoring the brand in the buyer's mind, will be examined on how they can be applied in order to achieve the goals of branding.

\section{The Role of Psychology in Brand Management}

The essence of a successful implementation of brand positioning, lies in the subjective brand perception of consumers. A profound understanding of how customers behave and which psychological processes influence them, is consequently vital for effective brand management. - Else, how will companies anchor their brand in the mind of the consumer, if there is no knowledge on which factors determine the target group's preferences among brands? Accordingly, it is indispensable to have an in-depth psychological understanding of consumer behavior, in order to find a good as well as prosperous position for a brand.

In virtue of the aspects mentioned above, the exigency for a systematic research in the area of consumer behavior, became evident. As early as in the forties of the preceding century, in the context of rather commercial issues, insights from psychology were utilized to bring light to economic behavior. In the last approximately thirty years, a rapid emergence of the exploration of buyer behavior and connected to this the establishment of the field in academic science as a distinct area of investigation, was observable. In the seventies and eighties consumer research experienced a nearly turbulent development - however, now the field is firmly founded as one of the core segments of marketing and marketing communication (Kuss \& Tomczak, 2004).

As documented above, the necessity for systematic research in the area of consumer behavior emerged and since many years borrowings from psychology are being made in order to illuminate the behavior of buyers. With regards to brand purchase situations, the psychological determinants of consumer behavior are frequently subdivided into on one side activating psychic processes that include images, attitudes, emotions and motivation and on the other side cognitive psychic processes to which perception as well as processing of information, information storage and information structuring, can be counted (e.g., Homburg \& Krohmer, 2005; Kuss, 1991; Meffert, 1992; Pepels, 2005). Activating are such processes that are linked to internal arousal as well as excitement and that stimulate behavior. Cog- 
nitive are such processes by means of which customers perceive themselves and their environment. The absorbed information - frequently as a result of communication - is then mentally processed and results in knowledge structures that impinge on the behavior of consumers (Kroeber-Riel, 1990).

The modern interdisciplinary research on consumer behavior is characterized by pluralism in theoretical concepts and empirical research methods. Not just one particular perspective dominates, rather different psychological research directions were pursued, depending on their appropriability to the existing problem (Kuss \& Tomczak, 2004). One of these approaches is the cognitive perspective on consumer behavior that considers conduct to be a result of information processing and interpretation processes (Peter, Olson \& Grunert, 1999). This view depicts buyer behavior as a problem solving and decision making sequence. The customer is portrayed as a recipient and handler of information who extensively seeks and evaluates the available alternatives. The outcome of this procedure can be buying behaviors such as brand selection or purchase repetition (Foxall, Goldsmith, \& Brown, 2002).

Buyer behavior seen as a problem solving and decision making sequence, often is contrasted with the behavioristic perspective which is another renowned approach to consumer behavior. One important difference between the cognitive and behavioristic approach, is the view on the decisive cause of behavior. From the behavioral perspective the focus lies on how the environment affects consumer behavior and while the cognitive perspective indeed also acknowledges that the environment affects behavior, furthermore the consumer to some extent has liberty on how this occurs (Foxall et al., 2002; Peter et al., 1999).

As elaborated above, there exists a broad array of psychological approaches that are relevant to predicting as well as influencing customer behavior and consequently, are meaningful to successful branding. Since an exhaustive analysis of all these approaches would exceed the scope of the present paper, in the subsequent chapters selected significant concepts and theories based on the cognitive approach to consumer behavior, will be reviewed.

\section{Cognitive Determinants of Consumer Behavior}

In context of the Cognitive Revolution in the sixties, it was acknowledged that customers can actively take influence on their environment and can initiate processes themselves by means of cognitive operations (Bagozzi, 1980; Mayer, 2005). Customers analyze buying situations, in consideration of prior experiences and then make evaluative judgments. Consequently, cognitive learning processes are useful in predicting buyer responses to branding activities and thus, are important to marketers (Moser, 1990).

Besides these cognitive determinants of consumer behavior, there are also activating psychic processes such as images, attitudes, emotions and motivation, which have significant influence on consumer decision-making. These activating determinants of consumer behavior lead to the fact that consumers do not merely act as passive recipients of marketing information but can take an active role in information processing as well as the decision-making process of which brand to purchase. Activating are such processes that are linked to internal arousal as well as excitement and are the driving force of behavior. Activating determinants of consumer behavior put the buyer in a state of enhanced attention and performance, to stimulate behavior and cognitive processing (Kroeber-Riel 1990).

From the Cognitive perspective, buyers are regarded as problem solvers who actively interact with their choice environment, search as well as take in communicated information from various sources, process this information and then make a selection among brands as well as make decisions. Above all, it lays emphasis on the significance of cognitive information processing for the explication of consumer behavior (Bettman, 1979; Meffert, 1998). Across situations, brands and consumers, the amount and depth of cognitive processing varies widely. Not in all cases are consumers engaged in extensive cognitive activity, in fact many behaviors and buying decisions involve minimal cognitive processing (Moser, 1990).

The cognitive processes taking place in purchase situations, are frequently divided into four sundry phases: perception, information processing as well as storage and structuring of information (Foscht \& Swoboda, 2005; Kroeber-Riel \& Weinberg, 1996). Consecutively, these individual phases will be analyzed in conjunction with their relevance to branding.

\section{Perception and Attention}

The perception and attention of buyers contains places or positions that a brand provider attempts to occupy. This is a facile task if the position is vacant, but tough if it is already occupied by rivals. In the latter case companies need to "reposition" their competition, in order to be able to enter the head of the consumer (Ries \& Trout, 1990). Purchase behavior relies profoundly on perceived attributes, some of which do not even have an objective reality. The intricacy for marketers, lies in having insight on what will be the general perception of the members of the market segments with whom they are attempting to do business (Blythe, 1997). Consumer perception therefore, has an essential influence on the behavior of customers and thus, is important to be considered while managing a brand (Behrens, 1982).

Consumers are subject to limitations in processing capacity. This suggests that the cognitive processes taking place during buyer decision making are fairly simple. Due to this limited capacity of the cognitive system, marketers should expect that buyers integrate no more than a small amount of knowledge when selecting brands (Bettman, 1979; Peter et al., 1999). Evidently in the Cognitive view, the prevalent problem of information overload finds consideration (Naisbitt, 1984). Customers underlying processing limitations, use rules of thumb 
that enable them to simplify buying behavior without requiring more processing capacity than available. These heuristics - rather than complex calculations - are used to make comparisons and choices among alternative brands (Zaichkowsky, 1995).

During the transformation of objective marketing stimuli into subjective perception, distortions can occur (Pepels, 2005). These perceptual distortions lead to the fact that the subjective perception of consumers, often differs from the objective reality. One distorting aspect is the selective nature of perception (Berndt, 1996). In the course of striving for cognitive relief, only a minor degree of the range of information, arising in conjunction with trivial buying decisions and acting on buyers, is made use of (Kuss, 1991). This perceptual selection takes place, because consumers' skills are limited and the quantity of alternatives offered to them increases daily. As a coping mechanism for this overwhelming choice environment, customers act as simplifiers of information and are incapable or not willing to involve themselves in extensive purchase decision making activities. Consumers' skills, way of life, values and goals determine the manner in which they seek as well as utilize communicated information, in order to make a decision on which brand to buy (Zaichkowsky, 1995).

One factor influencing the amount of information perceived by consumers, is the extent that they actively search for information. Based on the intensity and method of information search, consumers themselves can steer which stimuli that they want to be exposed to and which they rather want to avoid. Mainly consumers actively search for external information if they are activated and highly involved with the purchase. This in turn is dependent on the personality of the consumer (information inclination) and the environmental circumstances (perceived purchase risk). An example of such search for information can for instance be the targeted search for facts about computers before a computer purchase (Kroeber-Riel \& Weinberg, 1996; Ratchford, 2001).

Furthermore customers' perception of the environment is influenced and in part coined by their previous experiences, evaluations as well as by their capability to accurately process sensory stimuli. As a result of this subjective influence on stimuli interpretation, an identical object can be perceived by different people in various manners, as a function of existing experiences and ideals. This aspect of subjectivity has far-reaching implications on the effectiveness of brand communication - precisely because not the objective brand attributes or branding messages are decisive for consumers' decisions, but rather their personally coined input perception and processing (Kuss, 1991; Kuss \& Tomczak, 2004).

For branding the handling, control or perhaps even the manipulation of attention is crucial. If a brand is supposed to come out on top of other brands and be perceived, then it first of all has to lie in the consumer's field of attention. This demand is sharpened by findings according to which customers during purchase decisions solely take into consideration a fractional amount of the brands they know. Therefore a considerable part of competing brands is already excluded before it at all comes to an assessment - precisely because the attention of buyers is selective and thus, does not span the entire range of brands (Felser, 1997).

There are various strategies brand managers can apply in attempt to overcome the above mentioned challenges caused by the selective and limited nature of the cognitive system of buyers. Brand managers should try to save cognitive limitations - the goal is to achieve simplicity of messages without losing information (Böcker, 1986). A promising approach to deal with these cognitive limitations at the moment of designing branding measures, is the consideration of the principles from Gestalt Psychology underlying consumer perception. A fundamental Gestalt Law is the figure-ground separation in line with which, brand managers should make sure that the brand is salient and easily perceivable when presenting it to buyers in marketing communications in order to reduce the required capacity for perception and avert exactly such cases in which the figure - respectively the brand - is not immediately perceivable. This is crucial as a branding message that is not clearly recognizable, but rather only makes sense after lengthy inspection, doubtlessly will hardly outlive the famous two seconds that are granted to messages in an environment characterized by information overload (Ehrenstein, Spillmann \& Sarris, 2003; cf. Felser, 1997). Also Demangeot and Broderick (2010) emphasized the relevance of a Gestalt approach in their study of consumer perceptions in online shopping environments and stated that marketers are required to take Gestalt Psychology into consideration when trying to understand how consumers perceive online shopping environments.

In view of the prevalent information overload facing customers, another strategy to achieve simplicity of marketing messages without losing information, is by limiting content to the key message that is relevant to the brand and target consumer segment that the brand is attempting to address and be perceived by (Böcker, 1986; Mayer, 2005). To determine what content marketers need to focus on when designing branding messages for their target segment and also to ensure that the brand message is reaching the target segment in the desired manner, there are various Usability Inspection Methods that can be conducted with segment experts or representative target customer groups (for more details on these techniques please refer to Nielsen \& Marck, 1994).

To sum up, branding activities result in information being presented to buyers. Thus, how consumers interpret this communicated information is crucial for comprehending their response. Of particular and even increasing relevance to branding, is customers' limited capacity for processing information. In order to shelter from the continuously amplifying information flood, the brain selects and only takes in merely a fraction of the information and processes it further (Bettman, 1979; 
Homburg \& Krohmer, 2005). In virtue of these circumstances, it for obvious reasons is of utmost importance for brand management to be selective, to concentrate on a specific segment and to keep the branding message as simple and salient as possible, for example by referring to Gestalt Principles, in order to be able to penetrate into the long-term memory of customers (Ries \& Trout, 1981; Sawtschenko, 2005).

\section{Information Processing}

A common and meanwhile well-established approach to information processing in consumer research, is the multiple store framework (Kroeber-Riel \& Weinberg, 1996). With the aid of this Tristorage Component Model, the operations during information processing can be ordered and explained. In this context, also the above elucidated limitation of information processing capacity becomes pronounced, which in turn carries substantial bearing for the explication of purchase decision processes (Kuss \& Tomczak, 2004). With the procedure of information processing, environmental information is transformed into quantitative psychological values. As indicated in the preceding section, during this transformation distortions can occur which branding specialists need to be acquainted with, in order to be able to correctly assess the effects of stimulus mutations on consumer behavior (Behrens, 1982).

There are various sources of distortions during the process of information processing - one of them being the above elaborated information overload and the resulting selective and limited nature of the cognitive system of consumers. Further reasons for distortions and contextual biases can be the stimulus context that buyers finds themselves in when being exposed to marketing communications (Elfering \& Sarris, 2006). For instance a very thirsty person perceives an advertisement for a drink differently than somebody who is not thirsty at all (Homburg \& Krohmer, 2005). In general it can be said that distortions during the information transformation process usually are produced by unconscious additions, modifications (for instance through interference) or omissions (for instance through information decay) based on the buyer's characteristics, and take effect in the process of converting objective marketing stimuli into subjective impressions (Pepels, 2005).

There are a number of strategies on how to reduce the extent of such distortions, in attempt that the intended branding message reaches consumers in a suitable way. First of all by means of market research, the target consumer segment should be studied thoroughly: what are common life circumstances, current life goals, life experiences and contents of the long-term memory?

Then, one key approach is to make the content of the determined marketing message, emotionally relevant to the target audience. Emotions can possess an activating effect, seeing that buyers who are pointedly activated with emotional stimuli are more involved and respond cognitively in a superior manner. Emotions attract attention, which as elaborated in the prece- ding section, is a critical step in the perception process and can lead to reduction of distortions. Branding activities that trigger emotional arousal, are perceived with a higher likelihood than neutral ones and hence also consumers can remember brands better if they beforehand for instance were exposed to brand advertisement that evoked emotions. Put simply, emotions promote the efficiency of information transfer and of processing branding messages (Mizerski \& White, 1986; Werth, 2004).

Another way of promoting that brand messages reach consumers in a suitable way, is to increase salience by using appropriate media attended by the target group and - again in using these media following the Gestalt Principles when designing marketing communications, as they facilitate the information transformation process, reduce the potential of distortions and increase the probability of the branding message entering the long-term memory of consumers. One of the key assumptions of Gestalt Psychology that should be followed, is that perceptions organize themselves according to the principle of greatest Prägnanz - meaning that percepts arrange in the most balanced manner under the prevailing stimulus conditions. Thereby, it is important to keep in mind that - with rare exception of subliminal perceptual processes - cognitive consumer functions are active. Prägnanz of messages, however, increase the probability that consumer perception, attention control, memory function and decision making, as active processes, go along with marketing intentions (Ehrenstein et al., 2003).

The internal memory system comprises a Sensory Store, a Short-term Store and a Long-term Store. In all phases of processing and interpreting information, memory processes are involved and each of the mentioned memory stores possesses different properties and functions.

Information that is currently stored in the consumer's memory is utilized to interpret new inputs and - provided that the newly arriving information inputs are processed sufficiently - they can be retained as well. The fundamental internal memory system encompasses a very short-lived Sensory Store, a Short-term Store in which current processing is carried out and a Long-term Store where items of information are captured (Bettman, 1979).

The environment of customers, which contains a completely unmanageable vast amount of optical and acoustic information possibilities, constitutes the starting point of inspection. A part of the consumer's information processing system, the Sensory Store, for a short time passively saves detailed images of information that reaches the sensory organs. The Short-term Store only takes in a small part - of the sensory inputs processed in the Sensory Store - for further processing. There, information can be preserved for a couple of seconds, wherewith the processing and interpretation of stimuli is enabled (Foscht \& Swoboda, 2005).

In order to further process this information, the Short-term Store needs to draw back on the information (experiences) existing in the Long-term Store. The probability of percei- 
ving communicated information (e.g. a brand) is greater, if it is already contained in the Long-term Store and coherent with stored information. The information the Short-term Store has at command, either decays fairly fast or is taken over into the Long-term Store by means of learning. In the Long-term Store retention of the before processed information takes place on a long-term basis. Here, almost unlimited large information amounts can be maintained for a very long time. The goal of brand communication is to anchor the brand in the Long-term Store of the consumer (Kuss \& Tomczak, 2004; Trommsdorff, 2004).

Besides external information that is perceived via marketing stimuli, information can also be received internally. In this process, information that is saved in the Long-term Store is transferred into the Short-term Store - as for instance past experiences with a provider or the image of a brand. The information can enter the Short-term Store by consumers actively and consciously retrieving consumption experiences, or passively and coincidentally by means of associating memories. In many purchase decisions, consumers actively draw back on internal knowledge by means of transferring information that can help them during brand evaluation from the Long-term Store into the Short-term Store - as for example memories of past brand or purchase experiences. Hence for marketing, it is very important that the desired branding message is cemented in the Long-term Store of the consumer (Kroeber-Riel \& Weinberg, 1996).

Furthermore of course, consumers' involvement with a purchase decision, as well as other activating psychological forces, such as emotions, motivation and attitudes, determine the depth of cognitive processing that consumers choose to actively dedicate to the purchase decision-making process and to branding communications in general (Homburg \& Krohmer, 2005).

Central to branding are the associations that consumers connect with a brand, may those be product attributes, a celebrity spokesperson or a particular symbol. The driver of brand associations is a stable brand identity - what the company wants the brand to stand for in the consumer's mind (Rutschmann, 2005). As based on their cognitive capacity, past experiences and other factors, consumers store different information in their long-term memory, brand managers need to focus on presenting key branding information that the widest base of their target customer segment can relate to or have associations with in their memory that can be tied on to. A key method of penetrating into the long-term memory of consumers, is by addressing a generic schema in branding communications that is representative to the target group and which evokes the desired associations corresponding with the brand identity. Brand managers need to present clear beliefs, pictures and notions that they want consumers to link with the brand (Essig, Soulas de Russel \& Semanakova, 2003). For instance the brand Mercedes is a byword for safety and the reason that this image came to happen, is because Mercedes recognizes that safety is relevant to their target customers and hence addresses the safety scheme on a repeated basis in their advertising - creating a corresponding association between the brand Mercedes and this shared notion of safety. The technique usually employed to achieve this is Emotional Conditioning (Pepels, 2005).

Figure 1 shows how the entire cognitive information processing procedure can be illustrated with the aid of the Tristorage Component Model, in which the mental processing of stimuli takes place by means of the three annotated storage components (Bettman, 1979; Kroeber-Riel \& Weinberg, 1996).

\section{Figure 1}

S-O-R Model with integrated Tristorage Component Model. Based on Bettman (1979, pp. 139-141) and Foscht and Swoboda (2005, p. 74).

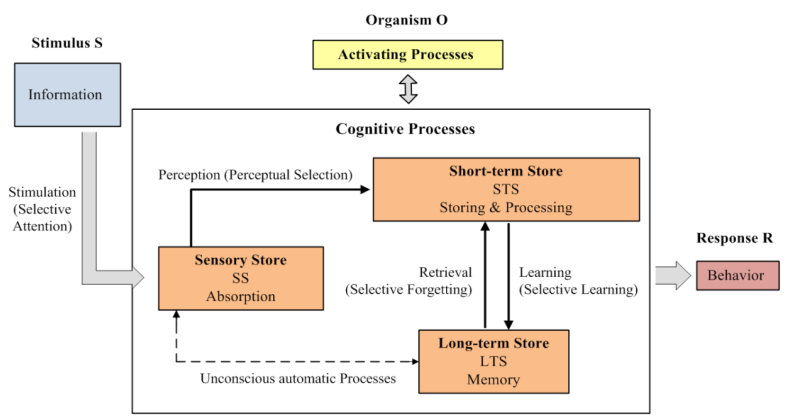

In applying these findings to marketing and communication decisions, brand managers can adopt two possible paths when defining a branding strategy. They can either offer as extraordinary and creative messages as possible, which more easily are cognitively perceived than others, are qualified as novel as well as relevant in the Short-term Store and are then, embedded in the Long-term Store. This path is often pursued by market challengers, who are not equipped with sufficient budget to outcompete the market leaders through market penetration - but however, see their minor chance in making up for their lacking resources by means of sensational branding and communication implementations. Or, another branding and communication strategy may bank on as much frequent repetition as possible, what unavoidably will be perceived cognitively at some point of time, is qualified as relevant as well as similar to already unconsciously perceived information in the Short-term Store and is then, anchored in the Long-term Store. This path is commonly adopted by brand leaders, who have ample of funds at command for market penetration and have a bigger need for security - what is scarcely compatible with the above mentioned sensational branding implementations (Pepels, 2005).

\section{Storage of Information}

After branding and communication measures have been perceived and processed, it is essential to make sure that the conveyed information is learned and retained as well. Only if branding messages leave behind traces in memory and the consumer can recall the factual and emotional contents in the 
purchase situation, branding takes effect. In order for brand managers to achieve this, the attention of the recipients of communication should be called to the essential and the communicated information amount should not be too large and should be narrowed down to a few key messages (Mayer, 2005). The information is saved in the Long-term Store and there can be retrieved and processed by the Short-term Store. The goal of brand communication of course, is to embed the brand promise in the Long-term Store of the consumer (Felser, 1997; Homburg \& Krohmer, 2005).

The cognitive processes involved in purchase decision making, are influenced by the consumer's knowledge in memory. Buyers' ability to remember meanings and their memory are central to marketers for the reason that buyers frequently do not make buying decisions at the time of exposure, attention and comprehension. Brand providers want consumers to keep in mind certain key features associated with their brand - such as brand name and benefits, as well as the main attributes of the brand (Peter et al., 1999). They rely on buyers to retain information they have acquired about brands, banking on that it will later be applied in buying situations. This internal memory is combined with external memory, which includes all brand details on packages, in shopping lists and other marketing stimuli that permit brand alternatives to be evaluated during the consumer decision making process (Solomon, 2002).

In case of frequently repeated contact to information, it is stored without own effort. Through confrontation with communicated branding messages over and over again or the repeated consumption of a brand, the consumer thus collects knowledge about its appearance, attributes, packaging and much more. This effect of repetition is vital in the prevalently saturated markets tagged by less involved buyers (see section Consumer Involvement), since consumers do not actively seek information on their own, due to the low purchase risk they face (Kuss \& Tomczak, 2004).

Another aspect related to information storage, is that the success of information conveyance addressing consumers with low involvement, is greater if images are employed for information brokering. Images demand less mental cognitive effort from the recipient, are widely processed automatically and are on account of this superiorly stored than words, in the case of lowly-involved customers (Kroeber-Riel \& Weinberg, 1996).

\section{Structuring of Information}

Information structuring refers to the lasting configuration of buyers' knowledge in their Long-term Store. Customers have structured systems of concepts concerning brands as well as brand providers and this knowledge regulates how environmental stimuli are perceived, processed and stored. Consumers' knowledge is organized to form knowledge structures in their memory and the representation of this knowledge is frequently modeled as Associative Network (Peter et al., 1999). The cognitive system creates net- works that depict the associative links between the beliefs that a buyer connects with a brand and indicate how information in the Long-term Store of the consumer is in correlation with one another. These links determine the usage of knowledge during information processing and novel incoming information is interpreted in consistence with the structures already in place (Kroeber-Riel \& Weinberg, 1996).

At first, a stimulus activates a specific concept in the memory of the customer and outgoing from there, the activation spreads over the whole network of associatively linked representations. Concepts connected by strong links more probably activate one another, than those connected by weak ones (Hoyer \& MacInnis, 2001). These relations are in particular characterized by brand knowledge, requirements and experiences. Such associations can for instance be created in a phonetic way, just like the manufacturer of the sunflower oil "Livio" who - by choosing this brand name - attempts to establish a positive consumer association to the higher-value olive oil (Felser, 1997; Homburg \& Krohmer, 2005).

A substantial amount of effort by brand managers is expended in influencing the Associative Networks that buyers have for provided brands. They need to monitor customers' knowledge structures and manage that knowledge. It is necessary for marketers to consider, what types of links they want buyers to form and to accordingly provide them with information to process. The nodes of a network linked to a brand can embody various brand attributes or furthermore, also celebrity endorsers of the brand or related brand providers, can constitute such nodes. Additionally with the aid of networks, marketers can elucidate existing knowledge structures, their development and changes in them (Hawkins, Best \& Coney, 2004; Solomon, 2002).

Therefore, the associations that buyers link to a specific brand play an important role for the purchase behaviors of consumers and to have notice of these customer associations is of particular bearing to brand management. Needless to say, the designation of brand communication is to boost consumers' positive associations with the brand as well as their affirmative thoughts related to the image of the company (Homburg \& Krohmer, 2005).

\section{Theory of Cognitive Dissonance}

After having analyzed cognitive determinants of consumer behavior in the antecedent chapter, our attention now shifts to an essential phenomenon in conjunction with cognitive processes, called cognitive dissonance. The Theory of Cognitive Dissonance put forward by Festinger (1964) states that if cognitions (e.g., attitudes, desires, intentions) are dissonant, that is conflicting, consumers actively keep away from situations as well as information that might add to the dissonance and are motivated to defuse this condition (Fulop, 1981).

Most purchase decisions involve dissonant feelings, since a state of dissonance often occurs when buyers must make a selection among brands. By choosing one brand and not another one, 
the buyer obtains the bad qualities of the brand purchased, as well as has to give up on the attractive features of the alternative foregone and this loss, leads to an unpleasant dissonant feeling (Hawkins et al., 2004; Solomon, 2002). Further, dissonance can origin from experiencing quality disappointments during brand consumption, from promoting information on rival brands or from the absence of social approval (Pepels, 2005). According to this theory, consumers are motivated to reduce the negative feelings caused by dissonance, by in some way making matters tally with one another (Fulop, 1981). This dissonance reduction can take place either by eliminating, adding or changing cognitive elements (Solomon, 2002).

Cognitive uncertainties can emerge as early as after exposure to communicated information, prior to the purchase (pre-purchase dissonance), following the purchase or not until the brand usage phase (Pepels, 2005). Cognitive dissonance that occurs after a purchase is called post-purchase dissonance (Schiffman \& Kanuk, 1997). Following the acquisition, customers may re-evaluate the brand in terms of whether it has satisfied their needs and if it fails, this can lead to dissonance (Blythe, 1997). After having bought a brand, consumers may use one of the following two approaches to reduce post-purchase dissonance. They can either boost the attractiveness of the brand purchased or decrease the attractiveness of rejected alternatives (Hawkins et al., 2004). Typically after a buying decision, customers have a quite selective perception for communicated information that a posteriori increases as well as supports the desirability of the selected alterative and depreciates the rejected brands (Festinger, 1964; Pepels, 2005).

Such consumer-initiated tactics, in order to alleviate dissonance by means of internal re-evaluations, can be backed by marketers through communication. For branding, one implication of the fact that consumers proactively search for messages containing additional external information supporting their choice, is that marketers are required to provide them with such purchase reinforcing inputs, in order to build a positive brand attitude and to nullify the eventual cognitive dissonance, arising from consumers' fear of having chosen a bogus brand (Felser, 1997; Hoyer \& MacInnis, 2001). Therefore, consumers' intensified receptiveness to communicated information following their purchase act, greatly enhances the role that follow-up branding and sales efforts can have. Many brand managers send recent buyers direct-mail materials, designed in large part to confirm the wisdom of their acquisition, so as to establish customer confidence in selecting that particular brand. Marketers may also make inquiry follow-up calls, in order to make sure consumers are not experiencing any troubles with the brand or the appliance as well as to reduce any dissonance and augment satisfaction (Hawkins et al., 2004).

Thus, a common application of the Theory of Cognitive Dissonance to minimize the dissonant feelings after a buying decision is found in endeavors of after-sales branding and com- munication activities. Such measures contain information that is provided to the buyer after brand purchase, in order to warrant it and to bring into prominence the specialties and benefits of the acquired brand (Felser, 1997; Moser, 1990). Measures to reduce dissonance bring about a stabilization and an increase of preference for the respective brand and with this repurchase behavior as well as brand loyalty (Mayer, 2005). Indeed, in absence of such follow-up branding to avoid or decrease dissonance, consumers may be more likely to select different brands in future or even trade their recent purchase earlier than initially planned (Foxall et al., 2002).

\section{Activation of Consumers}

The fight of information for a limited storage space, due to the prevalent information overload, most of all decides in favor of the information with the maximum activation ability. The greater the activation force of an information, the more easily it will be taken over into the Long-term Store. Stronger activating commercial messages are therefore, retained better and as a result can be recalled superiorly (Kroeber-Riel \& MeyerHentschel, 1982). With cognitive allurements mental conflicts, contradictions or surprises can be initiated that confront the customer's perception with unfamiliar tasks and thereby stimulate information processing (Homburg \& Krohmer, 2005). In consequence, brand managers who bring into play powerfully activating stimuli, can augment their success in influencing consumers and hence, activation techniques can be systematically deployed in order to enhance the effectiveness of brand communication (Kuss \& Tomczak, 2004).

The stronger the activation triggered by the stimuli, the more efficiently the presented information is absorbed. This effect starts with the caught attention, goes over the cognitive performance during information processing and ceases with a positive correlation between activation and memory power (Kuss \& Tomczak, 2004). The plausible consequence is that it is highly advisable for brand management, to maximize the activation force of branding measures and communications, in order to succeed in triumphantly cementing their brand in the mind of the buyer. Thereby, in this process, consumers are active participants and brand managers should acknowledge and study cognitive self-regulation habits. The active cognitive self-regulation habits include, e.g. use of media, multitasking habits, preferred modality use (visual versus acoustical channel use), depth of information processing, weighting of concurrent information etc. (Wang, 2007).

Furthermore, besides consumers merely being passive recipients of activating external stimuli, the active role that consumers themselves can take in the process of consumption decision-making, should not be underestimated (Homburg \& Krohmer, 2005). Of great significance in this conjunction, is the paper of Hennig-Thurau et al. (2010) which studied the impact that new media has on customer activity. According to this study, new media allows for customers to take an even 
more active part in the marketing and brand positioning process. Especially new media channels such as Google, Twitter and YouTube enable customers to take an increasingly active role as market players and have entirely changed how consumers gather, exchange and consume information about brands. Especially influential are social networks where based on user-generated content, consumers can actively search for information, share their experiences about brands and build relationships with other customers. Essentially, consumers have become highly active partners in the marketing process and are strongly connected with a network of other consumers. This results in extensive information being available on brands and products which can be beneficial, but also can potentially interfere with the company's branding message and make it more challenging to control the brand image. This new media's impact on customer activity, is a key factor that brand managers need to take into consideration when designing branding messages and attempting to influence consumer behavior (Hennig-Thurau et al., 2010).

\section{Consumer Involvement}

A target-oriented form of activation is involvement (Homburg \& Krohmer, 2005). The fundamental idea behind the involvement concept, is that the intensity as well as the quality of information processing, substantially is dependent on the consumer's perceived personal relevance of a purchase (Kuss, 1991). This relevance in turn, is determined by the buyer's needs and values (Felser, 1997). From a cognitive perspective, consumers experience involvement in a brand as cognitive perceptions of importance and therefore, customers' involvement at the time of exposure to communicated branding information, has major influence on their motivation to process and comprehend the message (Peter et al., 1999).

Varying with the type of brand in demand, involvement can exhibit a high or a low level (Homburg \& Krohmer, 2005). High involvement brands are characterized by a heightened activation level and an extensive search for information. Suchlike brand purchases bear relevant consequences for the customer and entail either a financial, social or psychological risk (Pepels, 2005). Highly-involved consumers will not easily be won over by branding measures and thus, are hard to persuade (Kiesler, Collins, \& Millar, 1969).

As already indicated in earlier sections though, the present market reality is rather tagged by buyers exhibiting a low degree of involvement (Pepels, 2005). In the case of low involvement, the buyer does not feel personally committed and thus, no more than a shallow information processing takes place, utilizing less and coincidentally perceived information (Kuss, 1991). If in such market conditions one brand becomes more familiar to the buyer than another one, this brand will be a more discriminate stimulus versus competing brands. For this reason in suchlike markets, a lot of brand communication can be observed that creates nothing but brand familiarity (Peter et al., 1999).
Usually, branding activities for low involvement brands should have relatively little information content and should be repeated frequently. In the case of high involvement brands, rather a lower number of messages that are rich in substance are recommended (Kuss \& Tomczak, 2004). All in all, branding specialists need to precisely know what level of involvement their target group brings along, in order to design their brand communication in such a manner that it manages to enter the mind of the consumer.

\section{Discussion}

The ambition of the present paper was to point out the relevance of cognitive dissonance, activation and involvement to branding and to show that the regard of these approaches may embody a key factor of success for brand management. Emphasis was laid on illustrating how knowledge particularly from the field of Cognitive Psychology, contribute towards an insight on consumer behavior and with this to effective branding.

The driver of the growing importance of brand positioning is that society in industrial countries is characterized by exuberance. In such a society of abundance, brands hardly anymore can be distinguished by means of functional properties and in consequence the psychological positioning of brands becomes indispensable. According to the definition of the named authors, it becomes apparent that positioning concerns the standing of the brand in the mind of the consumer. This paper has shown that in order to achieve such a designated standing of the brand, already since quite a number of years cognitive psychological theory is consulted.

In this overview, the Cognitive approach to consumer behavior was accentuated. Within the scope of cognitive determinants of brand purchase behavior, the selective nature of customer perception and the procedure of processing brand communication were emphasized. Furthermore, the chapter highlighted that branding measures only take effect, if they manage to leave traces in the consumer's memory and if they succeed in creating links between the brand in question and desired concepts.

The discussion of the Theory of Cognitive Dissonance pointed out a special case of customer cognition, elaborating how marketers can promote brand loyalty by facilitating cognitive consonance within the consumer. Concluding the body of the paper, the concept of buyer activation showed that by means of activating branding campaigns, the attention of customers can be grabbed and thereby information processing can be stimulated. To round off the paper, the involvement of buyers formed the focal point and revealed possibilities of dealing with the prevalent condition of lowly-involved consumers.

This paper has attempted to demonstrate how branding, through appropriation of insights from psychology, can obtain a differentiated psychological anchoring of the brand in the customer's mind. However, just as marketers apply their psychological understanding of consumer behavior, a host of 
ethical concerns arise and at this point words of caution are in order. According to the definition of Ries and Trout (1981) in the introduction, brand positioning involves taking influence on the mind of the buyer. But an issue open to debate is, where the ethical barrier of this psychological influencing rests (KroeberRiel \& Meyer-Hentschel, 1982). The major part of ethical concerns in this area, relate to the conflict between presenting a brand in a favorable light and presenting it completely accurately (Hawkins et al., 2004). Up to now, in the covered literature this issue is addressed only scarcely. It is essential to catch up this identified research gap and to dedicate future research to the mistrustfulness that has risen towards branding measures. These reproaches however, should not be looked upon as arguments against the use of psychological approaches for marketing and communication purposes, but rather should much more make plain that caution is due when applying them.

Even though within the scope of this overview, it was demonstrated how many potentialities, the application of psychological insights to buyer behavior in the context of brand management offers, at this point also attention should be called to its limits. The profound grasp of consumers' bearings, to be sure is utterly assistant to directing their behavior; however, the exact prognosis of buying decisions is impossible. Customers still have individual reaction scope and this fact drives home the confines of behavioral control and of psychological influencing, by means of branding measures (cf. Kroeber-Riel \& Meyer-Hentschel, 1982).

Further, in this overview several psychological models, theories and concepts were portrayed with the aim to help illuminate and forecast consumer behavior. It should be clear that buying patterns might not in all cases be explainable by theories and models, and that additionally other factors can influence the behavior of buyers as well. There may also be certain customers to whom the discussed approaches might not apply and alternative explanations may pertain, on how some buyers arrive at their purchase decisions.

Meaningful additions to this paper, various further psychological approaches could form like for instance, findings from Social Psychology which give more information on the social meaning of brands. This is chiefly relevant, seeing that a host of consumerbehaviorpatterns only become explicable when the purchase situation is viewed as taking place within a social context.

Furthermore, as already mentioned in earlier sections of this paper, a promising approach could be the consideration of principles from Gestalt Psychology underlying consumer perception, when designing (online) shopping environments (Demangeot \& Broderick, 2010). In connection with the present paper, this above all is especially relevant and advantageous in view of the indicated prevalent information overload facing customers.

The aim of the paper at hand was to review and to point out the relevance of psychological models and theories, particularly from a Cognitive perspective on consumer behavior, that are most commonly mentioned in published literature on the subject of branding. This paper should demonstrate how cognitive aspects, influence consumer behavior and thus, how having cognizance of these aspects is a decisive factor for the effectiveness of brand management and communication. The treated content constitutes an extract of an issue area which is of too wide scope, so as to be able to portray all the facets and the entire important literature in one single overview. Acknowledging the limitations of behavioral control and of the models as well as theories discussed, and recognizing the indicated supplementation possibilities of the paper, it can be stated that the present literature review was in a position to successfully illustrate which momentous contribution psychological approaches make to the comprehension of consumer behavior and in this way to prosperous brand management. Therefore, it is fundamental that the gained insights are implemented in branding, in order to thereby increase chances for successful business and competitive advantage in a saturated market.

\section{References}

1. Aaker, D. A. (1996). Building strong brands. New York: Free Press.

2. Bagozzi, R. P. (1980). Causal models in marketing. New York: John Wiley.

3. Behrens, G. (1982). Das Wahrnehmungsverhalten der Konsumenten [The perceptual behavior of consumers] (Reihe Wirtschafts-wissenschaften, Band 275). Thun: Harri Deutsch.

4. Berndt, R. (1996). Käuferverhalten, Marktforschung und Marketing-Prognosen [Buyer behavior, market research and marketing forecasts] (3rd Rev. ed., Reihe Marketing, Band 1). Berlin: Springer.

5. Bettman, J. R. (1979). An information processing theory of consumer choice. Reading, MA: Addison-Wesley.

6. Blythe, J. (1997). The essence of consumer behavior (Essence of management series). New York: Prentice Hall.

7. Böcker, F. (1986). Präferenzforschung als Mittel marktorientierter Unternehmensführung [Preference research as instrument of market-oriented management]. Zeitschrift für betriebswirtschaftiche Forschung, 38, 543-574.

8. Day, G. S. (1990). Market driven strategy: processes for creating value. New York: Free Press.

9. Demangeot, C. \& Broderick, A. J. (2010). Consumer perceptions of online shopping environments: A Gestalt approach. Psychology \& Marketing, 27, 117-138. http:// dx.doi.org/10.1002/mar.20323

10. De Pasquale, C. \& Leschnikowski, K. (2007). Models in der Werbung: eine empirische Untersuchung [Models in advertisement: An Empirical study]. Saarbrücken: VDM Verlag Müller.

11. Ehrenstein, W. H., Spillmann, L. \& Sarris, V. (2003). Gestalt issues in modern Neuroscience. Axiomathes, 13, 433-458. http://dx.doi.org/10.1023/B:AXIO.0000007203.44686.aa 
12. Elfering, A. \& Sarris, V. (2006). Memory and assimilation to context in delayed matching-to-sample. Psychology Science, 48, 17-38.

13. Essig, C., Soulas de Russel, D. \& Semanakova, M. (2003). Das Image von Produkten, Marken und Unternehmen [The image of products, brands and companies]. Sternenfels: Wissenschaft \& Praxis.

14. Felser, G. (1997). Werbe- und Konsumentenpsychologie: eine Einführung [Advertising and consumer psychology: An introduction]. Stuttgart: Schäffer-Poeschel.

15. Festinger, L. (Ed.). (1964). Conflict, decision and dissonance (Series Stanford studies in psychology). London: Tavistock Publications.

16. Foscht, T. \& Swoboda, B. (2005). Käuferverhalten: Grundlagen, Perspektiven, Anwendungen [Buyer behavior: Principles, perspectives, applications] (2nd ed.). Wiesbaden: Gabler.

17. Foxall, G., Goldsmith, R. \& Brown, S. (2002). Consumer psychology for marketing (2nd ed.).London: Thomson.

18. Fulop, C. (1981). Advertising, competition and consumer behaviour: public policy and the market. London: Holt Rinehart and Winston.

19. Hawkins, D. I., Best, R. J. \& Coney, K. A. (2004). Consumer behavior: building marketing strategy (9th ed., The Irwin / McGraw-Hill series in marketing). Maidenhead: Mc-Graw-Hill Education.

20. Hennig-Thurau, T., Malthouse, E. C., Friege, C., Gensler, S., Lobschat, L., Rangaswamy, A. \& Skiera, B. (2010). The Impact of New Media on Customer Relationships. Journal of Service Research, 13, 311-330. http://dx.doi. org/10.1177/1094670510375460

21. Homburg, C. \& Krohmer, H. (2005). Marketingmanagement: Strategie - Instrumente - Umsetzung - Unternehmensführung [Marketing management: Strategy - instruments - implementation - management]. Wiesbaden: Gabler.

22. Hoyer, W. D. \& MacInnis, D. J. (2001). Consumer behaviour (2nd ed.). Boston: Houghton Mifflin.Kiesler, C. A., Collins, B. E. \& Millar, N. (1969). Attitude change: a critical analysis of theoretical approaches (2nd ed., Series in psychology). New York: Wiley.

23. Kroeber-Riel, W. (1990). Konsumentenverhalten [Consumer behavior] (4th ed., Reihe Vahlens. Handbücher der Wirtschafts- und Sozialwissenschaften). München: Franz Vahlen.

24. Kroeber-Riel, W. \& Meyer-Hentschel, G. (1982). Werbung: Steuerung des Konsumentenverhaltens [Advertisement: Steering consumer behavior] (Reihe Konsum und Verhalten, Band 1). Würzburg: Physica-Verlag.

25. Kroeber-Riel, W. \& Weinberg, P. (1996). Konsumentenverhalten [Consumer behavior] (6th Rev. ed., Reihe Vahlens Handbücher der Wirtschafts- und Sozialwissenschaften). München: Franz Vahlen.
26. Kuss, A. (1991). Käuferverhalten [Buyer behavior] (Reihe Grundwissen der Oekonomik). Stuttgart: Gustav Fischer.

27. Kuss, A. \& Tomczak, T. (2004). Käuferverhalten: eine marketingorientierte Einführung [Buyer behavior: A marketing centered introduction] ( $3^{\text {rd }}$ Rev. ed., Reihe UTB Grundwissen der Ökonomik, Betriebswirtschaftslehre). Stuttgart: Lucius und Lucius.

28. Mayer, H. O. (2005). Einführung in die Wahrnehmungs-, Lern- und Werbe-Psychologie [Introduction to the psychology of perception, learning and advertising] ( $2^{\text {nd }}$ Rev. ed., Reihe Edition Psychologie). München: Oldenbourg.

29. Meffert, H. (1992). Marketingforschung und Käuferverhalten [Marketing research and buyer behavior] (2nd Rev. ed., Reihe Meffert Marketing Edition). Wiesbaden: Gabler.

30. Meffert, H. (1998). Marketing: Grundlagen marktorientierter Unternehmensführung: Konzepte, Instrumente, Praxisbeispiele: mit neuer Fallstudie VW Golf [Marketing: Principles of marketing centered management: Concepts, instruments, practical examples: With new case study VW Golf] (8th Rev. ed., Reihe Meffert Marketing Edition). Wiesbaden: Gabler.

31. Mizerski, R. W. \& White, J. D. (1986). Understanding and using Emotions in Advertising. Journal of Consumer Marketing, 3, 57-69. http://dx.doi.org/10.1108/eb008180

32. Moser, K. (1990). Werbepsychologie: eine Einführung [Advertising psychology: An introduction]. München: Psychologie Verlags Union.

33. Naisbitt, J. (1984). Megatrends: ten new directions transforming our lives. New York: Warner Books.

34. Nielsen, J. \& Mack, R. L. (Eds.). (1994). Usability inspection methods. New York: John Wiley \& Sons.

35. Pepels, W. (2005). Käuferverhalten: Basiswissen für Kaufentscheidungen von Konsumenten und Organisationen: mit Aufgaben und Lösungen [Buyer behavior: Basics for purchase decisions of consumers and organizations: With exercises and solutions]. Berlin: Erich Schmidt.

36. Peter, J. P., Olson, J. C. \& Grunert, K. G. (1999). Consumer behaviour and marketing strategy. London: McGraw-Hill.

37. Ratchford, B. (2001). The Economics of consumer knowledge. Journal of Consumer Research, 27, 397-411. http://dx.doi.org/10.1086/319617

38. Ries, A. \& Trout, J. (1981). Positioning: the battle of your mind. New York: McGraw-Hill Book Company.

39. Ries, A. \& Trout, J. (1990). Marketing fängt beim Kunden an: Taktik geht vor Strategie [Bottom-up marketing; Marketing starts with the customer: Tactic overrides strategy]. Frankfurt a. M.: Campus.

40. Rutschmann, M. (2005). Kaufprozesse von Konsumenten erkennen und lenken: mehr Marktanteil mit neuem Marketing [Recognize and steer buying processes of consumers: more market share with new marketing]. Heidelberg: miFachverlag. 
41. Sawtschenko, P. (2005). Positionierung - das erfolgreichste Marketing auf unserem Planeten: das Praxisbuch für ungewöhnliche Markterfolge: von der Austauschbarkeit zurAlleinstellung - die erfolgreichsten Praxis-Strategien für kleinere und mittelständische Unternehmen [Positioning - the most successful marketing on our planet: The practice manual for exceptional commercial successes: From interchangeability to monopoly - the most successful practical strategies for small and medium-sized businesses] (Reihe Gabal Management). Offenbach: Gabal.

42. Schiffman, L. G. \& Kanuk, L. L. (1997). Consumer behavior (6th ed.). Englewood Cliffs, NJ: Prentice-Hall.

43. Solomon, M. R. (2002). Consumer behavior: buying, having and being (5th ed., The Prentice Hall international series in marketing). Upper Saddle River, NJ: Prentice Hall.

44. Trommsdorff, V. (2004). Konsumentenverhalten [Consumer behavior] (6th Rev. ed., Reihe Kohlhammer Edition Marketing). Stuttgart: Kohlhammer.

45. Trommsdorff, V. \& Paulssen, M. (2005). Messung und Gestaltung der Markenpositionierung [Measurement and design of brand positioning]. In F. R. Esch (Ed.), Moderne Markenführung: Grundlagen, innovative Ansätze, praktische Umsetzungen [Modern branding: Principles, innovative approaches, practical implementations] (4th Rev. ed., pp. 1363-1379). Wiesbaden: Gabler.
46. Waller, G., Süss, D. \& Bircher, M. (2006). Die Markenpersönlichkeit als psychologischer Faktor der Markenwirkung [The brand personality as psychological factor of brand appeal]. Retrieved March 24th, 2008, from Zürcher Fachhochschulen, Hochschule für angewandte Psychologie: http:// www.hapzh.ch/download/F Markenprojekt_2006.pdf

47. Wang, A. (2007). Branding over Mobile and Internet Advertising: The Cross-media Effect. International Journal of Mobile Marketing, 2, 34-42.

48. Werth, L. (2004). Psychologie für die Wirtschaft: Grundlagen und Anwendungen [Psychology for Economics: Fundamentals and Applications]. Heidelberg: Spektrum.

49. Zaichkowsky, J. L. (1995). Defending your brand against imitation: consumer behavior, marketing strategies, and legal issues. Westport, CT: Quorum Books.

Received 25 April 2011

Received in revised form 1 September 2011

Accepted 8 September 2011 